\title{
Public Participation in Science and Technology: Performing and Obscuring a Political-Conceptual Category Mistake
}

\author{
Brian Wynne
}

Received: 27 September 2007 / Accepted: 2 October 2007 /

Published online: 23 November 2007

(C) National Science Council, Taiwan 2007

\begin{abstract}
In this paper, I attempt to explain how existing work in the science and technology studies (STS) sub-field of public engagement with, or participation in, public issues involving science and technology, has performed a serious category mistake in allowing itself to be called 'public participation in science' research. This requires us to reflect more systematically upon how our assumed objects, here the public issues we think we are dealing with, come to be 'objectified' in the forms which they do. Using the three sister papers, I make some conceptual distinctions which carry important political implications and corresponding analytical implications for STS. I suggest that the typical reduction of participation questions to ones of 'what qualification do publics have for engagement in expert practices?' is a mistaken distraction from more important questions which not only much analytical work, but also dominant practice, continues to ignore. This reductionist tendency even in social science and STS may tend to intensify, the more the issues reach across global networks and arenas. Finally, I suggest that STS work on public participation needs to enrich itself with some relevant political theory and philosophy, which would throw due historical perspective on the deeper forces shaping scientific understandings and normative representational performances of its 'democratic' publics.
\end{abstract}

Keywords Engagement · Participation · Defining public issues · Ignoring public concerns · Imagining and performing publics $\cdot$ Deleting difference $\cdot$ Erasing independent civic capacities

Brian Wynne is Professor of Science Studies and Associate Director of the UK ESRC Centre, CESAGen, at Lancaster University. He has recently been extending his research on how scientific discourses of public issues involving science, technology and risk project normative models of 'the public' into such public arenas, to include political economic changes in global techno-scientific cultures.

B. Wynne $(\bowtie)$

ESRC Centre for Economic and Social Apects of Genomics, CESAGen,

Lancaster University, Lancaster, UK

e-mail: b.wynne@lancaster.ac.uk 


\section{Introduction}

One of the pervasive problems in the endlessly escalating and globalising arenas of public reactions to what is called 'science' (or often its de-facto synonym, 'risk'), is the dearth of serious questioning of what is this object-'science'? 'risk'? 'uncertainty'? - which has usually been just taken for granted as the origin of meaning for all the actors involved. This also imposes a hugely problematic, unacknowledged normative commitment as to the subject-identities of those publics. The mushrooming academic field which claims to clarify these issues over 'public engagement with science' often appears uncritically to reproduce and reinforce those same actors' categories.

Public involvement in what used to be taken to be expert-only issues involving science and technology has typically been defined as 'public participation in science and technology'. Even much of the social scientific research on such issues, let alone practice itself, has typically failed to note the profound ambiguity in this common definition, which means it has also failed to identify its far-reaching political implications. Leaving aside for the moment the usual questions about 'publics' and 'participation', the less obvious question, which is often just presumed by all parties, is that about the supposed object of such processes - what is meant by 'science and technology' here? What is it that we imagine publics to be responding to, and sometimes attempting - even being invited - to participate in? Confusion and disagreement about these matters abounds, proliferating since long before the more recent globalisation of the western 'participatory turn' has gathered steam. ${ }^{1}$

In the last decade or so these participatory developments have spanned East and West in terms of geopolitical sites, actors and issues, as reflected in the three sister papers of this special issue; but they have also stretched to developing countries, indeed been preceded by developing country action in many cases (Cooke and Kothari 2002; Leach et al. 2005; Agrawal 2005). Regardless of the specific issue, location, or context, however, the conceptual and normative confusion indicated above is relentless. It has to be seen not simply as default of clarity, but more as a systematic practical expression of deeply intransigent, tacit structures of power embedded within those cultures of science, technology and their policy circles, including both academic and political habits-of-thought and practice.

In this review essay, I wish to highlight this syndrome as an essential part of the discussion of how we might approach a better and more sceptical understanding of the seemingly positive turn away from the one-way normative notion of public understanding of (i.e. deference to) 'science', to the supposedly two-way public engagement with this ambiguous and socially-constructed object (UK House of Lords 2000). Only then might we be able to move forward in a more constructive way. Some of the best analytical work in this field (e.g. Barns 1995; Goven 2006; Joss 1998; Irwin 2006) has demonstrated the unstated and unseen default processes by which entrenched powerful constructions of actors' capacities, agency, interests, concerns, rights, and identities, are silently reproduced, perversely through

\footnotetext{
${ }^{1}$ It may be more appropriate to call this a 'participatory return', since a similar mushrooming of such initiatives took place in the 1970s in Western countries, albeit with some significant differences.
} 
participatory processes which are supposed to be challenging those implicitly assumed categories in accountable ways. This points us as science and technology studies (STS) scholars towards bodies of existing work, in political theory and philosophy, for example (Young 1996; Benhabib 1996; Fung 2006; Fraser and Honneth 2003; Means 2002; Landes 1996; Gutmann and Thompson 2004; Taylor and Gutmann 1994; Bohman 2003) ${ }^{2}$ which takes us beyond the scope of most STS work in this domain (including the three papers in this volume, and until recently my own existing work). Such new intellectual connections could help us to begin to explain the historical antecedents of the profound fear and mistrustful paternalism which continues to characterise elite attitudes towards abstract bodies like 'the public'. This has to be seen as a profound inability and refusal of modern scientific culture, as mutually-evolved or co-produced with late-modern capitalism, to internalise, respect, and reflect difference. That is, this culture is profoundly parochial, and intrinsically closed and dogmatic in key respects - the very properties which scientific enlightenment was supposed to banish (Toulmin 1992).

I have suggested elsewhere (Wynne 2008) how the late twentieth century's huge and pervasive intensification of dependency on science has also willy-nilly intensified (1) the unnoticed dependency of that science upon a more-and-more extensive public credulity and trust in that techno-science, a 'trust' which had until recently just been taken-for-granted; and, related to this, (2) the unspoken need to evacuate ordinary citizens of any recognised capacity for independent, different collective meaningmaking, and corresponding knowledge rooted in different social needs, visions and priorities from those of elites as underpinned by science. In key cases, we can witness this moral and political evacuation as blithe lack of recognition on the part of scientific-technological elites that there is any 'public' dimension to their public commitments on behalf of society (Wynne 2008), as in the various grotesque misuses of public spaces in experimental practices of nuclear experts in the late twentieth century (like weapons testing, Kuletz 1998, but also deliberately excessive experimental discharges of environmental radioactivity from nuclear plants).

This alienation and denial of 'the public' can be argued to be growing, since its roots have been systematically misunderstood and misrepresented, as various versions of the 'public deficit model' rationalisation of public refusal to acquiesce in every such technological project. In its turn, this emphasises the challenges to institutions responsible for not just risk governance, but innovation governance (Felt and Wynne 2007), also to face up to the bigger responsibilities involved in not just organising public participation or engagement exercises, but in actually learning to respect, hear, understand and respond in terms to the issues which ordinary publics develop as concerns arising from their experience of innovation, science-asinstitutionalised, and their forms of governance (e.g. Marris et al. 2001; Kerr 2004).

The near-globalisation of the participatory turn has raised several interesting comparative cultural questions. For one example amongst many: what is the larger

\footnotetext{
${ }^{2}$ It is notable that while I am advocating that STS works to understand and integrate these political and philosophical perspectives into mainstream STS work on publics and techno-sciences, including ones which see no public dimensions to their technical practices, the reciprocal need is also evident - that these really valuable human perspectives should also work to take on board the insights of STS-SSK (sociology of scientific knowledge) which currently they lack.
} 
significance for participatory processes of what is seen as the typical Asian propensity to avoid overt disagreement, even if it is there in spades, and often ostensibly (Scott 1985) to defer to designated expertise and authority? However, most work has not really been sensitive to such cultural aspects. Instead, it has emphasised the commonalities which could be regarded as reflecting more universally modern science-centred conditions. Much of this work, therefore, has emphasised the reasoned, calculative, explicit, interests-based and deliberate or deliberative dimensions of such processes, and not the more subtle and difficult tacit, indirect, implicit and relational aspects. ${ }^{3}$ The political and philosophical perspectives which I suggest to be important, sit uncomfortably with this emphasis, and instead alert us to the latter dimensions. These more cultural aspects are occasionally evident in prevailing work, including the three sister-papers here; but they have been left quite disparate and fragmented, and need to be more systematically developed.

\section{Three Perspectives, Three Arenas: Similarity and Difference}

The three sister papers cover extremely disparate territories:

1. A survey review of the many different participatory dimensions of the agricultural biotechnology (GMOs) controversy in Europe, from 1994 to 2003, and across different EU member states;

2. Uninvited - and effective - local citizen participation in nuclear power decisions in Japan; and

3. A detailed 'internalist' analysis of two consensus conferences in Taiwan, on surrogate motherhood and prenatal testing;

Despite these very different substantive foci, contexts and analytical perspectives, there is a striking East-West convergence of analytical and methodological form. None of these papers was meant to be comparative across cultural boundaries, of course. Nevertheless, in setting their own scene in relation to other global STS work, they each still carry some such comparative substance, and this is framed in all cases by a highly rationalist conceptual form which does not naturally bring out any embodied and habituated cultural dimensions of such processes (Butler 1999; Bourdieu 1991; Welsh et al. 2007; Wynne 2001). Levidow's analysis of different aspects of the EU controversy over GM crops and foods probably most clearly delineates what can be seen as the interpenetration of, on one hand, interest-based

\footnotetext{
${ }^{3}$ To some extent this is understandable, legitimate and even necessary. Those more difficult, less direct and more historical cultural dimensions of such processes have initially to be approached largely through the medium of the direct and explicit; and it may be that once we could get this far, we might well find further commonalities as well as cultural differences. As the very embodiments of modernity, science and technology and their social-economic forms, including their controversies and conflicts, perhaps almost by definition can only be addressed in such calculative-reasoning terms, regardless of how they might be experienced. However, this does not mean that no substantive ontological difference is there. It would be quite mistaken to reproduce the dualist hole of assuming that the only form of such difference is that between the so-called modern and the so-called indigenous (de Castro 2004).
} 
strategic-calculative and deliberative reasoning processes in policy, and its shift towards participatory idioms to try to accommodate and domesticate mobilised public dissent; and on the other, more implicit, unreflexive, habit-shaped institutional processes and representations which automatically reinforced dominant assumptions, ideological stances, framings, and classifications - including classifications of what publics should properly leave to 'those who know better' on their behalf. Though Levidow naturally deals mainly in the former analytical idiom, he does also indicate where existing entrenched presumptions are just intransigently and 'blindly' performed. One such example is his account of the London Royal Society meeting where environmental NGO opponents and citizens were allowed to question selected GM scientists on technical issues, but were forbidden - on the grounds of 'not being scientific!'- to challenge them on the political statements the scientists had made, for example on the controversially-claimed benefits of GM crops. Thus, reflecting the object-ambiguity I referred to above, such politics is defined as science, and citizens are prohibited from engaging with this 'science'-protected politics. There is no evidence of deliberate scheming here, just of culturally-sedimented, presumptive and in-effect dictatorial habit. In such ways, time and again, publics are afforded no capacity and no right to become involved in the privileged normative social agenda which are pursued unaccountably through 'science', by powerful elites hemmed around by that ambiguous science, as (1) economic-technological production factor, (2) political agent, (3) tacit and potent ontological and normative classifier, and (4) putative public authority, as indicated above.

The limits of collective deliberation and participation, seen as the structured interaction of reasoned arguments and counterarguments, have been well-articulated by theorists such as Young (1996), Goven (2006), Means (2002), Fung (2006), and Bohman (2003), even if none of these political theorists have encompassed the distinctively problematic questions over 'science' which the STS of Goven has, for example, identified. It is as if the very imagination of 'participation' and 'publics' is inevitably already set, by the forms of power, imagination and material intervention embodied in the techno-sciences involved as ideological cultural forms in themselves (Franklin 1995; Wynne 2006). This indicates bigger issues for STS and the whole public participation field, which for all their interest and relevance, these three sister-papers are a priori unable to articulate.

In the light of those bigger questions over 'public participation in science and technology' indicated above, including about otherwise critical perspectives as in Levidow's neat notion of "biotechnologising democracy", further questions are suggested:

- How are the processes and actors, crucially including 'science' as discursively performed, imagining, and performing normative models of the publics putatively involved or not involved? This question applies to our own STS analyses, and not only to the actors processes we are analysing;

- What difference does it make, for the foregoing issues as well as for others, if we recognise that 'public engagement or participation' can be uninvited and not just, as is often taken as a definitive property of 'public participation', invited? This very notion of citizens requiring to be invited before they can 'participate', has 
already sold the pass in its implication that such citizens lack important qualifications to be autonomous public actors, especially ones which would enable them to coordinate and mobilise forms of independent collective meaning, knowledge, judgement and action, whether invited or not (Arendt 2005; see also Szerszynski and MacGregor 2006);

- How are implicit boundaries of public agency and involvement thus set and enforced in the very discursive-practical routines which are allowed to define such supposedly inclusive processes? Other examples here, as I have discussed elsewhere (Wynne 2006), are the reductionist definition of such public issues as 'risk issues' or even 'scientific issues', and the forms of reference to 'science' as assumed public authority which occur repeatedly yet highly ambiguously in public issues involving techno-scientific questions amongst many others (e.g. Goven 2006)

- Once we begin to see the sheer extent and powerful embeddedness of the fear and mistrust of 'the public' which is carried and exercised by the institutional owners, controllers, and representatives of techno-science, and once we see the systematic evacuation of any civilised capacity from them by such 'expert' actors, do we not need to start from somewhere more historically-enlightened, radical and challenging, than our normal conceptual and normative starting points in such issues?

For example, none of the three papers recognises the importance in this larger frame of reference of the conceptual distinction between invited and uninvited participation in issues called 'scientific and technological' issues. I deal with this more fully in the next section, in relation to the issue of public qualifications to engage in 'expert' questions. Juraku, Suzuki and Sukura describe very nicely just such a case, in which citizens independently mobilised themselves, according to their own concerns, meanings, resources, and issues, to alter the presumed momentum of a privileged self-appointedly exclusive expert nuclear commitment. That this was about a technoscientific object (but also about its institutional actors) does not make it a 'technoscientific issue'. Nor did the uninvited participation involve 'participation in science and technology'. To call it this is to grant silent power to the imposition of this normative frame upon the public issue and the public actors. They had different meanings arising from different ontological and relational commitments. It is to the importance of such difference that we need to draw critical attention, and to require that those powerful institutions of science reflect upon, in accountable ways. As techno-science is allowed dramatically to enlarge its material, symbolic, economic and psychological intervention into global social lifeworlds, the disruptive significance of this cosmopolitanist lacuna on the part of technoscientificcommercial-policy actors is bound further to intensify. According to its own terms, this will require ever more extravagant, provocative and ultimately futile forms of supposedly preventive action by mainstream institutions.

'Public engagement with science' processes which are still locked within existing premises are only ever likely to add to the incoherence and confusion, and to further confirm the mistrust of publics on the part of establishment actors. Many, including Levidow, here (e.g. Irwin and Wynne 1996; Kerr 2004; Marris et al. 2001; Goven 2003) have emphasised in various topical domains how, in issues which involve 
science and technology, many public concerns relate to the science (its exaggeration of control and predictive capacity; its unaccountable control and direction; its unrealism about or denial of relevant contingencies), but are not scientific issues, e.g. those publics are not disputing scientific assertions about risks, nor claiming to have expert authority. Yet when such public concerns are typically ignored — or maybe worse, translated into more domesticated terms and then said to have been addressed - our work does not usually recognise this as techno-scientific culture's systematic denial of 'the other', whether this be the 'epistemic other' of ignorance and associated lack of control, or the human other of ontological differences underpinning what are recognised only as mistaken public epistemic commitments.

The Taiwan consensus conference analysis by Chen and Deng is of course restricted only to invited forms of public participation in such issues, here both biomedical questions but also including the institutional, epistemic, cultural and political issues which can no longer, if they ever could, be relegated to merely derivative, 'contextual' secondary and tertiary issues. ${ }^{4}$ These are of course more difficult to bring into focus with relevant empirical data, but this has been done successfully elsewhere, including for consensus conferences (Goven 2006; Barns 1995; Joss 1998). In this paper, there are signs of such questions, as for example where the apt observation is made about participants' absorption and domestication of expert discourses into their own terms, and about vernacular development of discriminating attitudes towards unacknowledged expert contingencies and contradictions. But the empirical interest was not there for analysing and documenting the wider and longer-term processes which this sort of analysis would require. For example, there are analytical questions of what relevant public concerns may have existed, but (perhaps for reasons which Goven and Barns have, for example, identified in other cases) were not articulated within the formal process of the consensus conference and thus were excluded. Or there were questions about the proper agency of citizens to expose and challenge the imaginaries of biomedical scientists over social purposes, expectations, outcomes embedded in the 'technology' put forward, and over foreclosed alternatives. But these kinds of question were not addressed by the authors, so that further questions, about what may have happened with critical public commentary on such matters, had already been preempted by this stage. These appear to me to be more interesting and worthwhile analytical questions about consensus conferences and the usual repertoire of participatory methods, than attempting to discover whether participation in such events has changed attitudes or some technical understandings.

\footnotetext{
${ }^{4}$ This kind of framing which treats selected scientific questions as 'the' central issue, and relegates related questions about that science and its social relations to the 'contextual', is a much wider habitual classification which needs to be challenged. In its political aspect, for example in the EU GMO releases issue, the environmental risk assessments of a new GM construct proposed for commercial agricultural release are said not to include the 'coexistence' questions over contamination of other crops and foods with alien GM material, so that this issue is classed as an implementation issue only. It therefore cannot be used as a basis for deciding against a proposed release, even though it is an environmental risk matter. Such political classifications should themselves be the express objects of inclusive public deliberation with experts, but rarely if ever are.
} 


\section{Towards Reimagining Public Participation and its Objects}

In these respects at least, and despite some good analysis of other kinds, one can see how STS research can inadvertently become an agent of tacit rationalisation of deep structures of power which science as institutionalised co-constructs and naturalises. A major recognised issue here in analysing such participation processes with respect to science and technology is what we might call the problem of concreteness of option(s), or to invert this, the problem of assessing options not taken. Some such possible alternatives, which are by definition non-existent, cannot be imagined and considered, so however democratic a participatory process is in this respect is beside the point, unless a deliberate effort is also made to address the repertoire (or hegemony) of imagined futures which is being given material influence. This connects with the problem that such participatory exercises often become obsessed about representativeness, but never seem to recognise that where the particular risksimpacts being considered came from in the first place, that is innovation processes, are not remotely representative of, nor accountable to, wider social concerns and needs. All these commitments are just presumptively made, long before we come in the name of democracy and public interest, long before we come to the exercises in self-conscious 'public engagement' and 'participation' which all these assessments are focusing on, usually too far downstream in the life-cycles of innovation, regulation and impacts. The prior series of commitments is not at all democratic or accountable.

All of the participatory action and evaluation, of things like 'representativeness', especially as invited participation, never gets to address what research questions come to be seen as salient, with what imaginations of human ends and possible outcomes. This sociological interest in upstream phases like research and innovation commitments is not remotely about publics becoming involved in specialist scientific questions themselves. I have never heard any such advocates suggesting that we need 'democratic involvement' in deciding what factors influence alternative splicing in gene-protein relationships, or in anything of the kind. Nor do they claim public qualifications in such specialist expertise. This red herring should be despatched forthwith.

The central problem here, analytical and practical, is to expose and control the slide between 'technical issue', and 'public issue involving, but not confined to, technical issues'. This may well never become an entirely clear and unambiguous boundary, but that does not justify the rampant promiscuity and confusion of its continual transgressions. GM was a favoured assumed monolithic innovation, nuclear the same. Many biomedical trajectories embody similar hegemonistic tendecies such that alternatives are not usually discussed. Academic and practical public engagement should centralise this as a normative issue - no major innovation of these kinds should be entertained without a full and serious open-minded process of appraisal of not just risks, but of benefits-claims and promises, and of alternatives. Of course, this presents practical difficulties - of time, information, resources, maybe threatened investments already made. But these latter threats cannot always be allowed to rule indiscriminately, in the face of reasonable questioning.

In this series of analytical questions about material imaginations in science, technology and innovation and their publics, conventional visions and practices of 
public participation are exposed as seriously inadequate. Not only is it not a matter of claiming that publics know as well as experts in their specialist field; we should also not operate in the belief that citizens have well-articulated imaginations about what they believe to be desirable or possible in domains such as health, energy, agriculture and food. Thus, to expect such inputs as a currency of participation processes is optimistic, even if searching and salient questions will be posed of experts posing their own such imaginations. The point of this is surely to enforce wider social accountability of those normative techno-scientific technical-social imaginations through such exercises but also through the normal repertoire of spontaneous and independent, uninvited forms of civil participatory action. This kind of public participatory input to 'science and technology' is, again, not a claim of competence to deal directly with specialist technical questions, but to influence the 'social' (including the 'what is salient?', thus also the epistemic) which is embodied in and around techno-scientific cultures, and which is unaccountable under typical conditions. The three sister papers do not make nor develop this distinction, but in this they are in regrettably voluminous company. In conclusion I indicate one way of developing this.

\section{Conclusions: Public Qualifications and the Invited-Uninvited Difference}

One way of summarising much of the work on public involvements in issues involving science and technology is to say that forms of engagement which are in some way connected institutionally with policy making are both invited and have a preordained agenda and framing; and ones which are independent from institutional policy making are uninvited and independent, and thus normally have an agenda of issues and concerns, thus also a framing, which clash with that of institutionalised policy making and of policy-institutionalised science, too.

Uninvited public engagements usually arise in response to expert-led, expertjustified interventions and misrepresentations, exacerbated by further expert-led impositions of provocative and alienating definitions of what the issues and concerns are; thus also, by misrepresentation and lack of recognition of those publics themselves. Deliberately or not, invited public involvement nearly always imposes a frame which already implicitly imposes normative commitments - an implicit politics - as to what is salient and what is not salient, and thus what kinds of knowledge are salient and not salient (e.g. Cooke and Kothari 2002). Uninvited forms of public engagement are usually about challenging just these unacknowledged normativities. ${ }^{5}$ This does not require nor typically involve any claim to technical expertise, and as Chen and Deng found in Taiwan, most citizens spontaneously note their own inferiority and dependency on salient experts in this respect (see also Marris et al. 2001). Moreover, contrary to some such assertions

\footnotetext{
${ }^{5}$ It is notable, and disappointing, how a recent in-depth analysis and evaluation of the UK GM Nation? formal public debate (Horlick-Jones et al. 2007) just assumed that public participation as a social phenomenon, has to have a 'sponsor', thus 'in structural terms the sponsor of an engagement process may be regarded as its owner” (p. 25).
} 
(Kusch 2007; Kerr 2004; Collins and Evans 2003), claims to public qualification for this role are not romanticisations of public expertises, even though some publics do have specialist experience-based expertises.

The public qualifications issue has at least two aspects:

(1) Qualification to be involved in expert technical debate. This is the sort of issue which animates Collins and Evans for example, and which my own work has been mistaken to focus on as its primary concern; and

(2) Qualification to be involved in public issues involving technical expertise (for example, about the claimed future benefits, or opportunity costs, of specific research investments, or about how to assess scientific exaggeration of control in public issues). This includes qualification to be involved in challenging the normative social commitments projected and performed by science.

The second form of qualification above is about the collective societal definition of what the issues and concerns are which should enjoy priority public attention and attempted resolution. It is not unconnected with specialist technical expertises, and where appropriate it should be informed by these, but it does not at all reduce to this. Yet authors such as Kusch, and Collins and Evans, seem to think that the only relevant and valid public meanings in relation to science, are ones effectively given by science, so that the richness of legitimate different meanings, issues and concerns, including legitimately conflictual ones, is reduced to the singular dominant instrumental one of institutional science, usually wedded to its patronage interests of commercial ambition, and of knowledge as economic instrument.

In whichever kind of public issue involving science that is of interest, if the assumption is prosecuted in practice, that there is only one public meaning, as well as only one public knowledge, and that this is given by science, then policy so obsequiously subservient to scientific culture will always tend to dismiss and delete: independent civic capacities and collectivities (Laclau 2005); their definitions of what is important and relevant; and their knowledges. It will be correspondingly unable to respect difference. Thus for example, the mis-framing and misconduct of the GM debate in Europe will risk being repeated, in which as Levidow put it, the "government policies promoting specific technologies as if they were objective imperatives, thus promoting normative commitments to specific futures", will continue to provoke legitimate public dissent. In such circumstances, it is almost natural that perceived states of emergency have to be cultivated in order to fuel a public policy climate of "necessity", for example that citizens simply have to comply indiscriminately with technological programmes, in order to fend off the perceived dire threat from the new "Wild East" of the Asian Tiger 'knowledge-economies'.

In these respects, the further globalisation of the public participation front offers rich resources and opportunities to unpick the salient distinctions, nuances and issues. However, academic work in this field hangs rather in the balance, as it risks falling prey to the larger pressures on social science to deliver the policy agenda of securing the vacuous dream of public quiescence for the powerful commercial interests which act as global techno-sciences' patrons. If by default we uncritically reproduce the category mistake which identifies the public issues involving contemporary techno-sciences (including their political economic forms and imaginaries) as 'scientific issues', we have already stepped into that trap. Moreover, we will have betrayed STS as a public Springer 
intellectual responsibility. STS and its sister fields can only begin to achieve the more meaningful democratic role if they take seriously the work still to be done, on:

- Understanding the unacknowledged political-economic dimensions of today's techno-sciences, including their epistemic implications;

- Highlighting the normative models of 'publics' and human subjects which the scientific public knowledge of the ensuing policy culture enacts into society at large;

- Understanding how a key element of this tacit normative process is the 'expert' presumption that they know what the public issues are (hence, what public concerns are), while publics themselves, in effect, have no role to play in this;

- Charting the larger diversity of different human cultures and subcultures in which these kinds of normative scientific discourse intervene and provoke multifarious responses; and

- Systematically connecting all of this with the historical and philosophical perspectives on science as public knowledge, its constructions of 'publics', and with democratic political theory.

I have only indicated this intellectual - and democratic-programme in outline here. To take seriously these extra dimensions would help STS to engender the necessary extents of open and democratically accountable institutional reflection within and around science and its emergent global patrons. Only this can help break open the now-entrenched circles of political sycophancy, idolatry and mystification of science which support and indeed fuel the fragile political economy of endlessly escalating promise, fantasy and expectation, which now counts for 'reality' in such global circles. Only this further kind of sociology of public scientific knowledge can begin to expose, and help society to address, the unstated political and economic agenda - what do we collectively (aspire to) mean by 'public(s)'? - which is embedded within, and cultivated by, contemporary technoscience and its patrons.

\section{References}

Agrawal, A. (2005). Environmentality: Technologies of government and the making of subjects. Durham, $\mathrm{NC}$ and London: Duke University Press.

Arendt, H. (2005). The promise of politics. New York: Schocken Books.

Barns, I. (1995). Manufacturing consensus? Reflections on the UK national consensus conference on plant biotechnology. Science as Culture, 5(2), 200-216.

Benhabib, S. (Ed.) (1996). Democracy and difference: Contesting the boundaries of the political. Princeton NJ, and Chichester: Princeton University Press.

Bohman, J. (2003). Reflexive public deliberation: Democracy and the limits of pluralism. Philosophy and Social Criticism, 29(1), 85-105.

Bourdieu, P. (1991). Language and symbolic power. Cambridge, UK: Polity Press.

Butler, J. (1999). Performativity's social magic. In R. Shusterman (Ed.), pp. 113-128.

Collins, H., \& Evans, R. (2003). King canute meets the beach boys: Responses to the third wave. Social Studies of Science, 33(3), 435-452, June.

Cooke, B., \& Kothari, U. (Eds.) (2002). Participation: The new tyranny?, London: Zed Books.

de Castro, E. (2004). Exchanging perspectives: The transformation of objects into subjects in Amerindian ontologies. Common Knowledge, 10(3), 463-484.

Felt, U., \& Wynne, B. (2007). Science and governance: Taking European knowledge society seriously. European Union, Expert Group Report, EUR 22700. Brussels: European Commission D-G Research. Franklin, S. (1995). Science as culture, cultures of science. Annual Reviews of Anthropology, 24, 163-184. 
Fraser, N., \& Honneth, A. (2003). Redistribution or recognition? A political-philosophical exchange. New York and London: Verso.

Fung, A. (2006). Varieties of participation in complex governance. Public Administration Review, 66 (Supp1), 66-75.

GM Nation? The findings of the public debate (2003). London: Department of Trade and Industry. http://www.gmnation.org.uk.

Goven, J. (2003). Deploying the consensus conference in New Zealand: Democracy and deproblematization. Public Understanding of Science, 12, 423-440.

Goven, J. (2006). Dialogue, governance and biotechnology: Acknowledging the context of the conversation. Integrated Assessment Journal, 6(2), 99-116.

Gutmann, A., \& Thompson, D. (2004). Why deliberative democracy?, Princeton NJ, and Oxford: Princeton University Press.

Horlick-Jones, T. et al. (2007). The GM debate: Risk, politics and public engagement. Abingdon, Oxon UK, and New York: Routledge.

Irwin, A. (2006). The politics of talk: Coming to terms with the 'new' scientific governance. Social Studies of Science, 36(6), 299-320.

Irwin, A., \& Wynne, B. (Eds.) (1996). Misunderstanding science: Public reconstructions of science and technology. Cambridge UK, and New York: Cambridge University Press.

Joss, S. (1998). The Danish consensus conference as a model of participatory technology assessment. Science and Public Policy, 25(1), 2-22.

Kerr, A. (2004). Genomics and society: A sociology of disease. London and New York: Routledge.

Kuletz, V. (1998). The tainted desert: Environmental and social ruin in the American West. New York and London: Routledge.

Kusch, M. (2007). Towards a political philosophy of risk. In T. Lewens (Ed.), Risk: Philosophical Perspectives (pp. 131-155).

Laclau, E. (2005). On populist reason. London and New York: Verso.

Landes, J. (1996). The performance of citizenship: Democracy, gender and difference in the French revolution. In S. Benhabib (Ed.), pp.295-314.

Lewens, T. (Ed.) (2007). Risk: Philosophical perspectives. London: Routledge.

Leach, M. Scoones, I., \& Wynne, B. (Eds.) (2005). Science and citizens: Globalisation and the challenges of engagement. London: Zed Books.

Marris, C., Wynne, B., Weldon, S., \& Simmons, P. (2001). Public attitudes to agricultural biotechnologies in Europe, PABE, final project report, EU FP6. Brussels: D-G Research, FAIR programme.

Means, A. (2002). Narrative argumentation: Arguing with natives. Constellations, 9(2), 221-245.

Pimbert, M., \& Wakeford, T. (2002). Prajateerpu: A citizens jury/scenario workshop on food and farming futures for Andhra Pradesh. Economic and Political Weekly (India), 32(27), 2778-2787, (Review of Science Studies: 6-12 July).

Scott, J. (1985). Weapons of the weak: Everyday forms of peasant resistance. New Haven: Yale University Press.

Shusterman, R. (Ed.) (1999). Bourdieu: A critical reader. Oxford, and Malden MA: Blackwell.

Szerszynski, B., \& MacGregor, S. (2006). Environmental Citizenship and the Administration of Life, draft paper, Lancaster University Centre for Science Environment Technology and Culture, CSEC, Dept. of Sociology.

Taylor, C., \& Gutmann, A. (1994). Multiculturalism: Examining the politics of recognition. Princeton, NJ, and Chichester: Princeton University Press.

Toulmin, S. (1992). Cosmopolis: The hidden agenda of modernity. Chicago: Chicago University Press.

UK House of Lords. (2000). Science and society. UK House of Lords, Select Committee on Science and Technology, London.

Welsh, I., Plows, A., \& Evans, R. (2007). Human rights and genomics: Science, genomics and social movements at the 2005 London social forum. New Genetics and Society, 25(2), 123-135.

Wynne, B. (2001). Expert discourses of risk and ethics on GMOs: Creating public alienation. Science as Culture, 10, 445-481.

Wynne, B. (2006). Public engagement as means of restoring trust in science? Hitting the notes, but missing the music. Community Genetics, 10, 211-220.

Wynne, B. (2008). Update: A quarter-century retrospect. In B. Wynne (Ed.), Rationality and Ritual: The windscale inquiry and nuclear decisions in Britain. London: Earthscan (republication of original 1982 version, with update chapter, British Society for History of Science).

Young, I. (1996). Communication and the other: Beyond deliberative democracy. In S. Benhabib (Ed.), pp. $120-136$. 